\title{
Understanding the Interconnectedness of International Trade Theories: A Case in Point of Cuba in Transition
}

\author{
https://doi.org/10.21272/sec.3(1).27-41.2019
}

\author{
Bahaudin G. Mujtaba, D.B.A. \\ Nova Southeastern University, Huizenga College of Business \& Entrepreneurship, USA \\ Pedro F. Pellet, Ph.D.
}

Nova Southeastern University, Huizenga College of Business \& Entrepreneurship, USA

Jatuporn Sungkhawan, D.B.A.

International Advisory Associates Co., Ltd., Southeast Bangkok College, Thailand

\begin{abstract}
This paper summarizes the arguments and counterarguments within the academic discussion on the issue of international trade and various barriers that hinders it. The main purpose of this article is to provide an overview of several foundational international trade theories related to exporting, importing, and trade restrictions for the national economy of a small socialist country, Cuba, with the United States of America. Some citizens are against trade between these two countries due to differences in political systems. However, the solution and relevant approaches for solving this trade restriction problem lies in effective and peaceful negotiations toward a brighter future, rather than allowing past conflicts to prolong the status quo of trade barriers. The relevance of the decision of this scientific problem is that modern data from 2018 indicates that most Cuban-Americans are in support of better relations between the Cuban and the United States governments. As such, we provide a historical review of politics, as well as economic growth and trade decline between the United States and Cuba over the past century to demonstrate how we got to this point of devastating embargos and restrictions in business, which hurt consumers.
\end{abstract}

The methodological tools of the research for this paper are literature review, history of politics based on personal experiences of the authors with the two countries, and other secondary sources along with documented interviews with respondents from South Florida during November-December 2018. Investigation of the international trade barriers between Cubans and Americans in the paper is in the sequence of literature content, Cuban history and politics, personal analysis and discussion, and recommendations. As part of this process, foundational trade and economic theories such as comparative advantage and absolute advantage are covered and applied to trade between Cuba and the United States. Thus, we explain trade concepts for application in the context of Cuba as a case in point.

Overall, the paper presents the findings of experts and empirical study results, which shows that both Cuban and American entrepreneurs and consumers can benefit from better trade relations between the two countries. The recommendations of this paper can be useful for policy makers and government officials in both the United States and Cuba. Towards the end, besides an academic overview of Cuban politics and trade, we provide suggestions and recommendations for decision-makers and those involved in international relations.

Keywords: international trade theory, balance of trade, trade restrictions, absolute, comparative and competitive advantage, factor endowment, Cuba.

JEL Classification: F10.

Cite as: Mujtaba, B. G., Pellet, P. F., Sungkhawan, J. (2019). Understanding the Interconnectedness of International Trade Theories: A Case in Point of Cuba in Transition. SocioEconomic Challenges, 1(3), 27-41. https://doi.org/10.21272/sec.3(1).27-41.2019.

(C) The Authors, 2019. This article is published with open access at Sumy State University. 


\section{Introduction}

Trade has always been an everyday business activity since ancient times. However, today it is an important source of prosperity and wealth for most nations, governments, organizations, and entrepreneurs that strategically plan for it. Through various trade agreements, countries are now trying to achieve trade liberalization through open markets, lower tax rates for businesses, and free trade zones in order to maintain and increase their competitiveness.

A fact of the modern global world is that trade between nations can be advantageous for the citizens or nationals of each country. International trade has helped many nations to pull themselves out of stagnant economies and grow into prosperous countries, thereby providing each citizen or nation the opportunity for a better quality of life (Mujtaba, 2014b; Luthans \& Doh, 2018). International trade offers opportunities for the poor, developing, and developed nations to grow and become stronger. As such, it is important for public sector policy makers, entrepreneurs, and international managers to better understand global trade and implement relevant practices that can bring the utmost benefits of trade to their citizens and nationals (Mujtaba, 2015). Countries and regions trade with each other not only when they do not have the goods and services they require for their own needs but also they trade to export their surpluses to other countries or regions (Berger, 2018; Gilpin, 2018). The development of the modern world and the emergence of the global economy can be explained, at least partially, due to increase of international trade and cultural convergence due to modern technology (Luthans \& Doh, 2018). Imports from around the world are now a necessary element of our life, as they may be less expensive or, at times, of better quality. Consumers often find that products from other countries are more appealing due to the additional features they offer and most of them are now easily available locally or through online retailers. Trade among states is essential for countries to obtain goods and services that are not available within their own borders, because either resources are not indigenous to these nation-states, or production technology is lacking. This is certainly the case for the Caribbean Island of Cuba as they can help American businesses and Americans can gain from Cuba's rich culture and products that Cuba can produce more efficiently. We have chosen Cuba, as a case in point for our discussion, since many American entrepreneurs could not access it over the past five decades. The methodology used for this paper is a brief literature review of the foundational trade concepts discussed in most elementary economic class, and the personal experiences of the authors in both cultures of Cuba and the United States of America.

\section{The Island of Cuba}

Christopher Columbus discovered the island of Cuba to Europe in 1492. It became one of the stops of the Triangle trade between Europe, Africa and the Americas. African slaves were dropped off in Cuba to work in the sugar cane fields to export sugar to Europe and North America. For several hundred years, Spain had claimed Cuba as their own until the second half of the XIX century when Cuban forces revolted against Spanish rule. At the time, the young country of the United States interceded on Cuba's behalf to fight off the Spanish until 1898 when Spain was forced to gave up claims to Cuba and surrendered it to the United States.

In 1902, Cuba became officially independent; however, it relied on US protection and in return allowed the US to intervene in Cuban affairs. In 1933, an army sergeant named Fulgencio Batista was democratically elected President of Cuba and President Gerardo Machado was overthrown. The U.S. intervention partially ended around 1934; but in 1953, a native lawyer by the name of Fidel Castro attempted to overthrow Batista regime, however he failed. Castro was sentenced to 15 years in prison but Batista pardoned him and he retreated to Mexico after serving two out fifteen years of jail sentence, to regroup and garner support for another coup attempt. Castro returned to Cuba in 1956 and collaborated with Argentinian guerilla fighter Ernesto "Che" Guevara to plan for another coup. By 1958, the U.S. had officially withdrawn military aid to Batista, so the island was to fend for itself. Revolutionary forces representing different political ideologies successfully overthrew Batista in 1959. By rallying its citizens and selling them an idea that he would return Cuba to the people, many Cuban citizens backed several rebel leaders including Castro.

By 1960, Fidel Castro had taken over and nationalized all businesses on the island, including American firms that were established on the island. In 1961, a failed CIA led invasion called the Playa Gir'on or Bay of Pigs invasion officially cut diplomatic ties between the U.S. and Cuba. By this time, Castro had established a revolutionary state and turned to the former Soviet Union (Russia) for sponsorship and support. 
In 1962, Castro welcomed the Soviets by allowing the Russian military to secretly build nuclear missile installations across the island as a threat to the U.S. When President Kennedy caught wind of the activities, he began a careful dialog with the Soviet leader Nikita Khrushchev to prevent further action and avert a nuclear war. The thirteen days of talks produced a U.S. military blockade of all Soviet ships into the island. As cooler heads prevailed, the Soviet ships turned back and the U.S. government vowed not to take military action to destabilize the Castro regime on the island. The U.S. however did impose an embargo on the island nation as to drive it to economic isolation and possibly spark a popular movement to overthrow the Castro dictatorship. The South Florida data from 2018, conducted by researchers at the Florida International University (FIU), demonstrates that most Cuban-Americans of all age groups believe that the embargo has not worked well or not at all (see Figure 1).

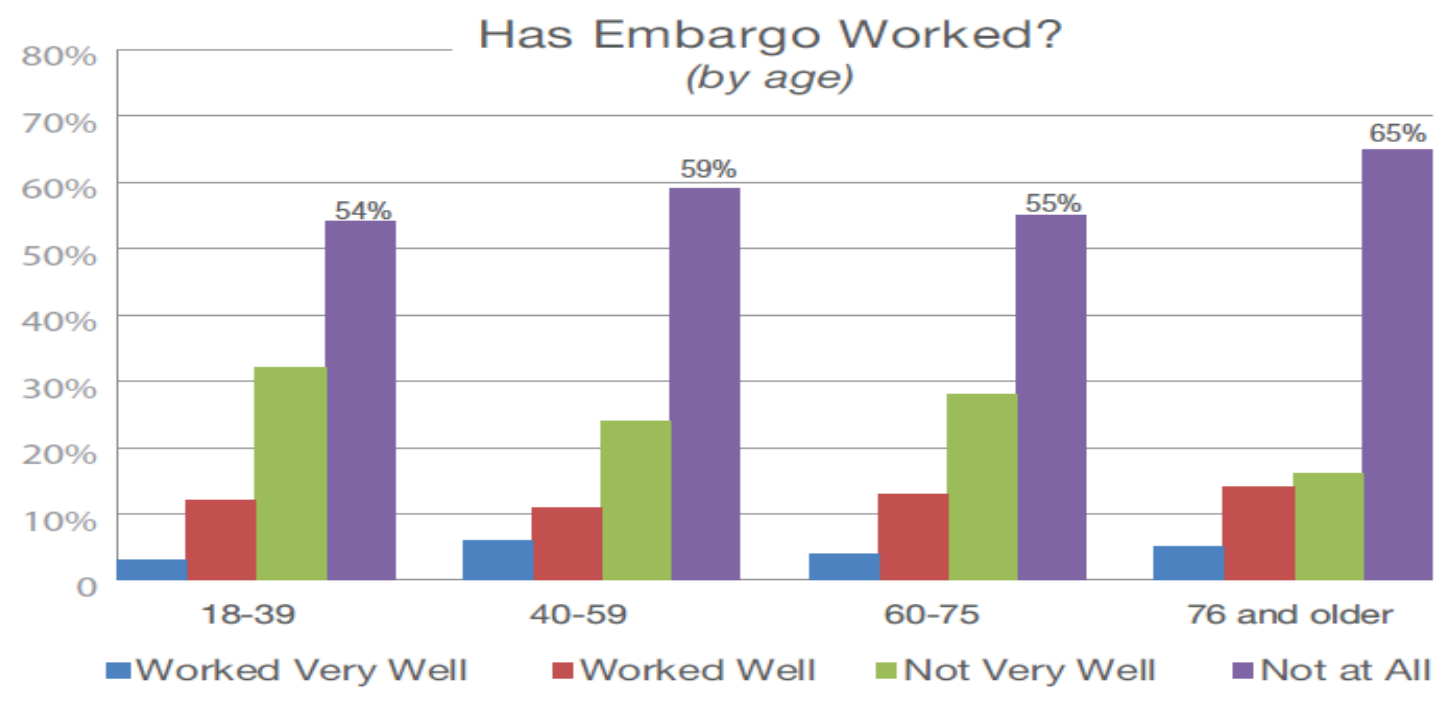

Figure 1. Impact of U.S. Embargo on Cuba

Source: Grenier and Gladwin, 2018, p. 9 (Link: https://sipa.fiu.edu/academics/research/2018-fiu-cuba-poll.pdf).

Despite the tightening US embargo, Cuba was aided by the Soviets. The partnership survived until 1991 when the USSR collapsed. From that point on, the island went through an economic collapse that saw little to no growth. In the early 2000s, Cuba partnered with Venezuela to trade Cuban physicians, teachers, and military advisors for Venezuelan oil (Piccone and Trinkunas, 2016). Following the death of Fidel Castro in 2016, the Cuban government, led by Fidel's brother, Raul Castro began to ease commercial restrictions on the island in the attempt to spark economic growth. In the same year, President Obama visited the Cuban island with the intent of easing the restrictions of the embargo. That visit became historic as he became the first sitting American president to visit Cuba since Calvin Coolidge in 1928. Some people believe that the island is not what it once was during its golden years of the 1950s; however, some are optimistic that the fortunes can change on the island (BBC, 2018).

During its economic height, Cuba was the most industrialized nations in Latin America and one of the most developed. The U.S. had invested heavily in the Cuban infrastructure as over 50\% of Cuban railroads and over $90 \%$ of its phone and power industries were American owned. Cubans enjoyed a very high per capita income and lived within a North American cost of living standard. Cuban industries such as petroleum, mining, non-sugar manufacturing, construction, and tourism all saw growth during this period. American enterprises saw profits totaling more than $\$ 375$ million between 1952 and 1958 (Wolfe, 2016). In today's dollars, that would have come out to $\$ 3.5$ billion. Havana was famously known as a paradise (a vacation heaven) for the rich and famous. Hollywood's elites would vacation and party on the island's beaches and nightclubs. However, as of 2018 Cuba ranked 179; or near the bottom of Index of Economic Freedom list of 180 countries (Marsh, 2018). Today, the top income tax rate in Cuba is 50\%; and top corporate tax rate is $30 \%$. In addition, recently published data shows that most Cubans are overwhelmingly supportive of American firms selling food products to consumers in Cuba (Grenier and Gladwin, 2018, p. 12). 


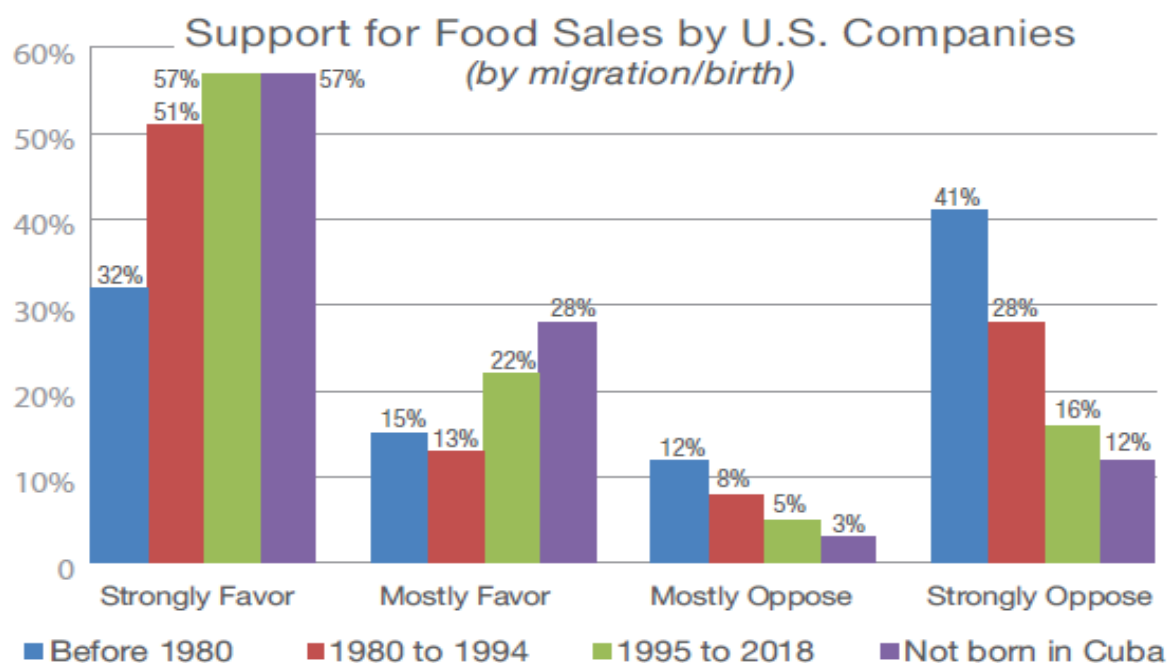

Figure 2. Cubans Supporting Food Sales by American Firms

Source: Grenier and Gladwin, 2018, p. 12 (Link: https://sipa.fiu.edu/academics/research/2018-fiu-cuba-poll.pdf).

Much of trade restrictions with the United States is attributed to the totalitarian system in place in Cuba, as the government owns much of the businesses and means of production. Corruption is a problem throughout institutions in Cuba. Since much of the commercial market is government controlled, black markets permeate the marketplace and gives the typical citizen an avenue to obtain items normally not available on the island. Since people will demand variety or options and may go underground to get it, it makes sense for the Cubans and foreigners to do business in a transparent manner.

\section{Trade among Nations}

Nations trade with each other because each country benefits from it by getting something they want, thereby leading to win-win outcomes in exports and imports (Gilpin, 2018). When managed properly, international trade allows nations to prosper in a sustainable way, while improving their economies on a continuous manner (Mujtaba, 2014a). When a country produces and exports that in which it has an absolute or comparative advantage, or those goods it can produce most efficiently than others, and then it imports products from other countries that it produces less efficiently, consequently, it benefits through trade (Berger, 2018; Luthans \& Doh, 2018). Consumers enjoy the benefits of trade because they have more varieties of products and services to choose from, all at a lower average total cost. Because of international trade, wages and standards of living increase in countries around the world (Sanyal, 2006). Those countries that do not participate in international trade miss these benefits and are more prone to sluggish economies.

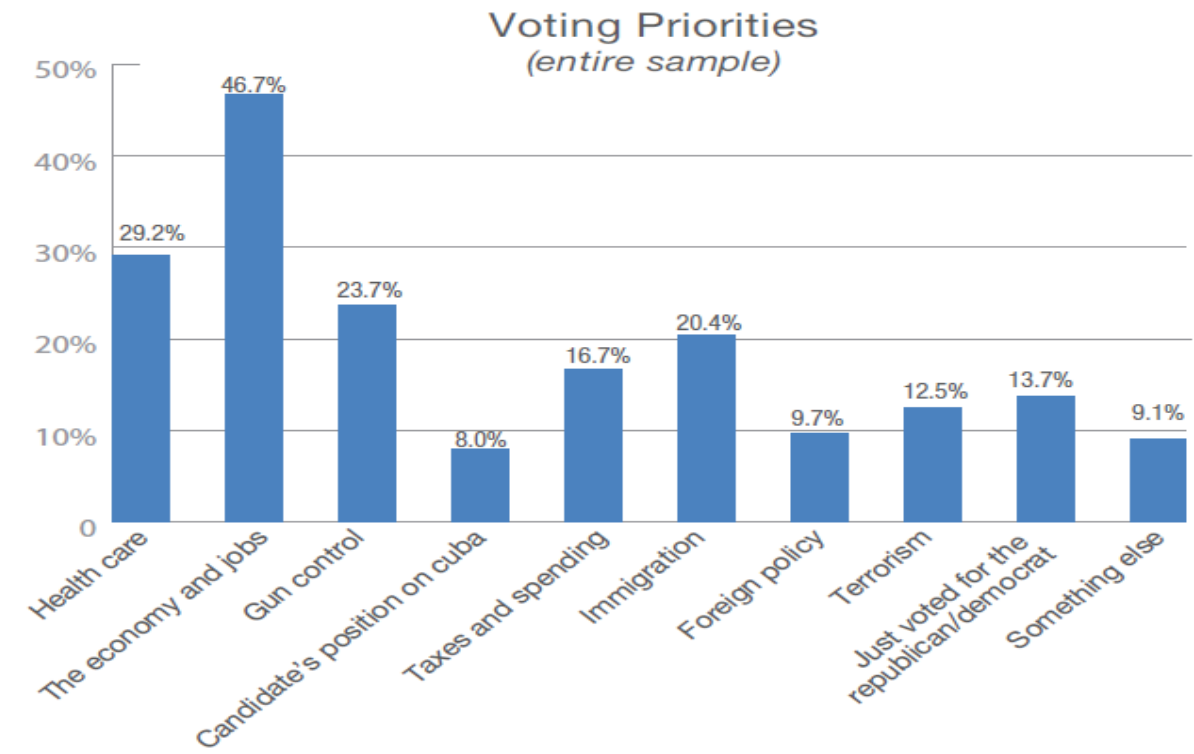

Figure 3. Cuban Voting Priorities 
Source: Grenier and Gladwin, 2018, p. 28 (Link: https://sipa.fiu.edu/academics/research/2018-fiu-cuba-poll.pdf).

Grenier and Gladwin $(2018$, p. 7) survyed a random sample of over 1,000 Cuban-Americans living and working in South Florida. Telephone interviews were conducted with 1,001 Cuban-Americans depending on the respondent's language preference and 69\% preferred to speak in Spanish. As shown in Figure 3, similar to most citizens in the United Sates, a significantly large number of Cuban-Americans are concerned about the economy, jobs and healthcare. As such, trading internationally with Cuban consumers and other neighboring states are a priority for the American economy.

It has been said that, "In the world of international trade, there are always winners and losers, but as economists have long argued, the benefits to the winners outweigh the costs borne by the losers, resulting in a net gain to society" (Hill, 2011, p. 160). Economists believe that trade causes economies to grow and increases standards of living (Berger, 2018; Sanyal, 2006). Both developed countries and those that are developing or poor can benefit from international trade. For example, Bangladesh has a comparative advantage in the production of textiles; entrepreneurs and workers in Bangladesh can produce most textiles very efficiently and cost effectively, thereby offering very affordable garments to consumers around the globe. The efficiency of production at reasonable prices benefits Bangladesh by boosting its economy, as more orders will come to them and it benefits consumers around the world who can purchase new and colorful garments at a fairly lower price.

While countries benefit from fair and open international trade, so do private citizens and entrepreneurs who are the catalysts for today's global marketplace (Berger, 2018; Gilpin, 2018). Today, individual entrepreneurs and innovations can have ownership rights over intellectual property through patents, copyrights, and trademarks. Generally, and especially in a capitalist environment, a patent grants the inventor of a new product or process exclusive rights for a definite period to the manufacture, use, or sale of that invention. Copyrights are the exclusive legal rights of authors, composers, playwrights, artists, and publishers of various products to publish and disperse their work as they see fit for a profit or on a pro bono basis (Berger, 2018). Trademarks are designs and names by which entrepreneurs, merchants, or manufacturers designate and differentiate their products in today's global marketplace (Sanyal, 2006).

\section{International Trade and Globalization}

Today, international trade takes place in the context of a global market. The globalization of markets refers to the idea that historically distinct and separate national markets are merging into a single, huge global marketplace that can be accessed by anyone at any time using cyberspace technologies (Gilpin, 2018; Mujtaba, 2010). For example, big multinational firms like Coca-Cola, Starbucks, and McDonald's offer the same basic product worldwide, and are in fact, not only a part of the trend, but facilitators of the trend as well. The most global markets are not actually for consumer goods, but instead are for industrial goods and materials that serve the same needs across the world.

The globalization of production refers to the sourcing of goods and services from locations around the world to take advantage of national differences in the cost and quality of factors of production. Companies that capitalize on this trend are able to outsource production to the best suppliers in the world and therefore should end up with a better final product.

The concept of "first-mover advantages" are the advantages that accrue to early entrants into a specific market (Mujtaba, 2014b). Late-mover advantages are the handicap that late entrants might suffer from. For companies, early entrants into potential future economic stars may be able to reap substantial first-mover advantages, while late entrants may fall victim to late-mover advantages (Sanyal, 2006).

In terms of a definition, international trade is simply the exchange of consumer or capital goods and services between countries for the mutual benefit of their citizens or nationals. International trade gives rise to an interdependent world economy, in which prices, or supply and demand, affect and are affected by global events. Political change in one part of the world could result in an increase in the cost of labor, thereby increasing the manufacturing costs for a company in another continent, which would then result in an increase in the price that customers have to pay to buy their products at a local mall. A decrease in the cost of labor, on the other hand, would result in a customer having to pay less for the company's product. Trading globally 
gives consumers and countries the opportunity to be exposed to goods and services that are not easily available in their own countries. There are two major types of international trade (Hill and Hult, 2017), which are bilateral and multilateral trade.

Bilateral international trade is a trade agreement in which two countries exchange goods and services. It occurs when each country tries to balance its payments and receipts separately and individually with each other.

Multilateral international trade is a type of international trade in which a country trades with many other countries. This ensures international division of labor among several nation-states based on their natural endowments.

Because of international trade, almost every kind of product can be found on today's global market: food, clothes, computers, smartphones, spare parts, oil, jewelry, wine, stocks, currencies, water, etc. Services can include tourism, banking, healthcare, education, consulting, and transportation. A product that is sold to the global market (outside of one's own country) is an export, and a product that is bought from the global market into one's country is an import.

Global trade allows countries to use their resources whether labor, land, technology, or capital more efficiently as they sell or export to others products that they can produce more efficiently and buy services from foreign nations that are cheaper to import. Because countries or regions are endowed with different assets and natural resources (land, labor, capital, and technology), some countries can produce the same good more efficiently and therefore sell it more cheaply than other countries. If a country cannot efficiently produce an item, it can obtain that item by trading with another country that can produce it; this concept is known as specialization and exchange.

\section{Trade Flow Theories}

In this section, due to the nature of this paper and page limitation requirements, we provide an overview of just a few basic or foundational trading concepts for those who are novice on this topic.

Mercantilism, or commercial capitalism, was the first modern theory of international trade, which is still being practiced in some corners of the world. The main tenet of mercantilism is that it is in a country's best interests to maintain a monetary trade surplus by exporting more than it imports (Kenton, 2018). By doing so, a country would accumulate gold and silver and, consequently, increase its national wealth, prestige and power. Consistent with this belief, the mercantilist doctrine advocated government intervention to achieve a surplus in the balance of trade (Mercantilism, 2018). The flaw with mercantilism has been that it viewed trade as a zero-sum game in which a gain by one country resulted in a loss by another country (Kenton, 2018; Mercantilism, 2018).

Adam Smith's theory of absolute advantage, David Ricardo's theory of comparative advantage in the $18^{\text {th }}$ and $19^{\text {th }}$ centuries, Heckscher-Ohlin-Stolper-Samuelson's Theorem on comparative advantage, Raymond Vernon's ideas on the product life cycle, and Paul Krugman's new $20^{\text {th }}$ and $21^{\text {st }}$ centuries trade theories are some concepts that policy makers, international managers, and trade researchers should learn and reflect upon before making major policy decisions.

Absolute Advantage (Adam Smith, 1723-1790). Adam Smith's main argument was that countries do not all produce at the same efficiency levels. This leads to Smith's theory of absolute advantage, which states that a country has an absolute advantage when it can manufacture or produce something more efficiently than any other country. He said that a country "should specialize in the production of goods for which they have an absolute advantage and then trade these goods for goods produced by other countries" (Hill, 2011, p. 163). Adam Smith was of the mindset that government should minimize its involvement in international trade through the imposition of quotas and tariffs, as the "invisible hand" should guide the market instead. The market force, which is often unobservable, helps the demand and supply of goods in a free market society to automatically reach a level of equilibrium, and this concept is known as the "invisible hand".

Comparative Advantage (David Ricardo, 1772-1823). David Ricardo agreed with Adam Smith that countries should produce that product or service which they can produce more efficiently than other countries, but he further opined that a country should "buy the goods that it produces less efficiently from other countries, even if this means buying goods from other countries that it could produce more efficiently itself" (Hill, 2011, p. 166). The main point of David Ricardo's theory is that it is based on a country's labor productivity; and perhaps it can lead to a better level of balance in international trade among neighboring nations. 
Heckscher-Ohlin-Stolper-Samuelson's Theorem. Eli Heckscher and Bertil Ohlin along with their colleagues supplemented the comparative advantage theory by stating that a country should export goods that use its abundant factors intensively, and import goods that use its scarce factors intensively. They stated that differences in national endowments such as land, labor, and capital affect a country's comparative advantage.

Product Life-Cycle Theory (Raymond Vernon, 1913-1999). The Product Life-Cycle Theory (PLCT), developed by Raymond Vernon in the mid-1960s, suggested that most products are produced and exported from the country where they were first developed. Then once the product is widely accepted, other countries begin to produce it. Once the product reaches this stage, it might be exported back to the original country where it was first produced.

New Trade Theory: Paul Krugman's Perspective. The new trade theory is based on the idea that the world can only support a limited number of firms. It proposed that firms that manage to be first-movers in an industry end up gaining an advantage because other new firms will not find it as easy to join the market. Paul Krugman's theory also focuses on economies of scale, which are unit cost reductions with large-scale output.

The theory of international trade is based on the principles of: 1) absolute and comparative advantage developed by Adam Smith (1723-1790) and David Ricardo (1772-1823), respectively, who were members of the Classical School of Economics; 2) the Heckscher-Ohlin-Stolper-Samuelson's theorem on comparative advantage; 3) the Raymond Vernon's (1913-1999) significant contribution to the product life cycle, and 4) Paul Krugman's new trade theory. These are foundational concepts that policy makers, international managers, and trade researchers should learn.

Adam Smith's theory of absolute advantage states that a country or a region should specialize in the production of goods and services for which it has an absolute cost advantage over another country or region.

David Ricardo's theory of comparative advantage states that a country or region should specialize in the production of goods and services for which it has a comparative advantage over another country, that is, the ratio of output to input for one good or service shows a sufficient advantage to more than compensate for the disadvantage in the ratio of output to input of another good or service. This will bring about an overall lower production cost for the country. Overall, Ricardo's theory suggests that consumers in all nations can consume more if there are no restrictions on trade. This occurs even in countries that lack an absolute advantage in the production of any good. To an even greater degree than the theory of absolute advantage, the theory of comparative advantage suggests that trade is a positive-sum game in which all countries that participate realize economic gains.

Economies of scale are unit cost reductions associated with large-scale output. The new trade theory suggests that a country may predominate in the export of a good simply because it was lucky enough to have one or more firms among the first to produce that good. Furthermore, the first movers' ability to benefit from increasing returns creates a barrier to entry.

Without trade, each country must consume what it produces. By engaging in international trade, two countries can increase their combined production of those goods that it produces most efficiently to buy the goods that it produces less efficiently from other countries, and consumers in both nations can consume more of both goods. It should be noted that firms and nations only thrive in trade if the environment and policies are fair and unrestricted.

\section{Unrestricted Free and Fair Trade between Nations}

Unrestricted free and fair trade between nation-states means that the government does not interfere in trade, thereby imports and exports are allowed without restrictions, tariffs, and quotas (Seyoum, 2014). Free and fair trade allows countries with an absolute advantage to manufacture and export those items they can produce more efficiently than other countries rather than producing whatever the government wants them to produce (Sanyal, 2006). They are also able to purchase goods and services from other countries that produce them most efficiently, therefore enabling consumers to buy products at lower cost. Many advantages are gained through this process as participating countries acquire more than they would if they produced everything themselves. As a result, there are more varieties of products to choose from, products and services cost less, wages are higher, and standards of living improve in countries around the world. 
Free trade refers to a situation where a government does not attempt to influence through quotas or duties what its citizens can buy from another country or what they can produce and sell to another country (Sanyal, 2006; Porter, 1990). Common sense and experience suggests that some international trade is beneficial. Theories by Smith, Ricardo, Stolper-Samuelson, and Heckscher-Ohlin suggest that a country's economy may gain if its citizens buy certain products from other nations that could be produced at home. The gains arise because international trade allows a country to specialize in the manufacture and export of products that can be produced most efficiently in that country, while importing products that can be produced more efficiently in other countries.

\section{Governments' Role in Competitive Advantage}

Policy makers in government should play a strategically proactive role in promoting national competitive advantage in certain industries. Government regulations and policies greatly affect a country's potential to compete, and although this governmental involvement may at times have a detrimental effect on a country's success, it may help to support a country's competitive advantage (Mujtaba, 2014b).

The United States, even though it is already a developed economy, can improve its transportation infrastructure and land use planning if it wants to remain sustainability competitive in today's global economy (Reid, 2008). Nowadays, we see that other national economies such as India, China, and the EU are upgrading their infrastructures and even airports using modernized standards and technologies.

Michael Porter's Diamond describes the four characteristics that affect a country's ability to compete nationally and internationally, thereby producing sustainable competitive advantage. They are factor endowments, demand conditions, related and supporting industries, and firm strategy, structure, and rivalry.

Factor endowments. Factor endowments can be "basic," which occur naturally since a country cannot easily change climate, natural resources, geographic location, and demographics (Porter, 1990). Of course, factor endowments can be "advanced," which a country can affect over time with relevant strategic investments, such as skilled labor, communication infrastructure, research facilities, and technology.

Demand conditions. Demand conditions focus on how local demand for products can affect innovation. Porter argued, a nation's businesses gain competitive advantage if their local consumers are sophisticated and demanding. As such, studying international trade concepts, policies and procedures through higher levels of education become important for gaining a sustainable competitive advantage.

Related and supporting industries. Related and supporting industries within each nation can help an industry become strong internationally. Knowledge is shared between these related industries, giving them all a sustainable advantage.

Firm strategy, structure, and rivalry. The final attribute in gaining a sustainable national competitive advantage is firm strategy, structure, and rivalry. A country's management ideology affects how well it can compete internationally. For example, Germany, China and Japan have many well-educated and specialized engineers, which enabled these countries to have excellent manufacturing processes and product designs. Another thought of Porter's is that if a country has domestic rivalry, firms will have to become very efficient and innovative to be competitive, and that leads to better quality products and lower costs. As a result, these firms become much better able to compete both nationally and internationally.

Government involvement and relevant regulations in all of these above-mentioned areas can either help or hinder a country's competitiveness. Research has demonstrated that factor endowments can be affected by subsidies, policies toward capital markets, policies toward education, and so on. Government can shape domestic demand through local product standards or with regulations that mandate or influence buyer needs. Government policy can influence supporting and related industries through regulation and influence firm rivalry through such practices as capital market regulation, tax policy, and antitrust laws (Porter, 1990).

It is been hypothesized that a government's choice of policies can positively or negatively impact national advantage. Furthermore, "regulation can alter home demand conditions, antitrust policies can influence the intensity of rivalry within an industry, and government investments in education can change factor endowments." (Hill, 2011, p. 182). Therefore, the amount of government intervention through policies and regulations that affect a plethora of nation-wide conditions can have a great impact on a country's competitiveness in world trade. 
In the new developments in the world trading system, policy makers should emphasize the importance of location for all production activities in order to maintain a sustainable competitive advantage. For example, a firm that produces laptop computers, which require different stages of production, i.e., research and development, manufacture of standard electronic parts, manufacture of advanced electronic parts, and final assembly, can have each of those production stages handled in the part of the world that can handle it most efficiently. Of course, before considering dividing the production of a product into several different locations around the world, a firm must be aware of trade barriers that will impede its ability to do this efficiently. Such barriers can include tariffs on exports and quotas. In some cases, a country may selectively impose trade barriers on certain countries due to political challenges among them.

Entrepreneurs and multinational corporations should lobby their governments to invest in education, infrastructure, and research, and to adopt relevant policies that will help each organization maintain a sustainable competitive advantage both domestically and internationally. Governments should carefully consider regulations related to antidumping policies, trade quotas, and tariffs to make sure local consumers and entrepreneurs are not at a disadvantage. In addition, firms and government policy makers should continually invest in upgrades, efficiency, technology, as well as in research and development.

\section{The Demand for Trade in Cuba}

In regards to technology, while Cuba has had its share of growth, it is considered to be a country that has experienced limited modern development (Flores, 2016). For example, even in 2018, most Cubans have very limited access to the internet as their technologies are somewhat inefficient compared to the world, especially when compared to the United States or Europe (Al Jazeera and news agencies, 2016). One of the driving forces behind trade as well as globalization is advances in technology, especially communication, and for that reason, development of the internet infrastructure and improvements in internet accessibility will increase the economic development of the country. This development will benefit both Cubans and Americans for additional trade.

\section{Cuba's History and Politics}

The Republic of Cuba is a country with a history of political instability and economic uncertainty. Originally, under the control of Spain, Cuba was liberated during the independence war of 1898, and founded in 1902 (US State Department, 2016). In 1959, a revolution drove the government towards a totalitarian pseudo-Marxist-Leninist regime (Kapcia, 2012; Pellet, 1986, 2014).

The revolution led by Fidel Castro beginning in January 1959 resulted in a totalitarian Cuba (Pellet, 1986), nationalizing all private business (Burnett, 2015). The government allied with the Soviet Union, setting it at odds with the nearby United States, which responded with over half century of trade embargoes that have negatively impacted the Cuban economy. These trade restrictions made it illegal for most American businesses to conduct trade with Cuba.

An international incident nearly brought the United States and the Soviet Union to war when Cuba was used to stage Soviet weapons of mass destruction within close range of American borders. Political tensions during this period illustrated the contention between capitalist and communist ideologies and governments.

The Cuban Revolution leader Fidel Castro died in 2016. Following his retirement from leadership, some progress has been made towards lessening trade restrictions and increasing the opportunity for private business within the country (Sweig \& Bustamante, 2013). A major development has been the moves towards the elimination of an inefficient dual-currency system (Symmes, 2015). These changes have been gradual and limited, as the dual currency system is in place and it is still illegal for companies in the U.S. to own interests in Cuba.

Though access to the country is limited, there is potential benefit both for the Cuban economy and foreign investors introducing capital into the economy to move towards direct trade. As restrictions are lifted over time, these benefits can be realized when approached with the appropriate strategy.

Cuba is a pseudo centrally planned economy. Prior to the overthrow of the U.S. supported authoritarian leaders, Cuba was a major exporter of sugar to the U.S. as well as a popular tourist destination for Americans (Flores, 2016). After the revolution and the conversion to absolutism, the economy was both inefficient and 
restricted by internal trade and external embargoes. Internally, the Cuban government, having nationalized businesses and exercising total control, restricted the country's access to the world market, engaging in trade according to government directives, not market influences. Externally, the country was limited by trade and travel restrictions put in place by the United States in an attempt to contain a conflicting political and economic ideology.

The revolutionary and counterrevolutionary efforts of Fidel Castro were inspired by his extreme opposition to a free enterprise and democratic political system. A command economy is ideologically incompatible with the free market capitalism of the United States and interactions between the two involve special considerations. Free markets are driven by the incentive to achieve a profit on investment through production or providing services. The interaction of producers and consumers constitutes a market and that market is driven by many interacting forces. In capitalism, those forces are left to their own natural outcomes with few government regulations. These regulations and controls, such as a trade barriers or environmental restrictions, considerably influence the market but do not control it to the extent of a command economy.

The control of the market is left to the producers and the consumers, with production and prices being driven by the market forces of supply and demand with limited influence by the government. This free market capitalism becomes a part of the country's culture, its set of societal norms governing behavior. American culture features a strong emphasis on personal success and individualism. This emphasis drives entrepreneurial investment and the development of new opportunities. Markets that have yet to experience the rapid development of globalization appeal to investors and opportunity seekers, but there is a cultural difference between the potential investor and the potential emerging market.

Socialism values the collective interests of the community over the few. The desire for personal success that drives the capitalist is a conflicting concept to the socialist regimes. The revolution, though it resulted in an inefficient economy, was inspired by the ideology of a country for the people ensured by the paternalistic government. When group-centered values are firmly established in a culture, attempts to enter into the market with a conflicting ideological approach are seen as invasive. It was for this reason that the communist country struggled for decades to limit free market influences.

One of the primary differences between capitalism and communism is the difference between economic and political freedom and control. A capitalist market is free to pursue its own self-interest. A communist country controls the market and decides the people's interest for them. For example, access to the internet is a freedom that allows for the accumulation of knowledge that encourages personal decision-making. Personal decisionmaking often promotes one's self interest.

The primary beneficiary within a command economy are the members of government. As the government determines production and distribution, those in control enjoy the greatest quality of life while those controlled are limited to the conditions that result from government policy. The incentive for the government controllers, then, is to maintain control. External influences that incentivize political change are a threat to both their control and their livelihood.

\section{Cuba and the United States of America in Trade}

International trade not only results in increased efficiency but also allows countries to participate in a global economy, encouraging the opportunity of foreign direct investment (FDI), which is the amount of assets invested by foreign entities. In theory, economies can therefore grow more efficiently and can more easily become competitive economic participants and partners.

One such example of this partnership can be Cuba and the United States of America, as it was until 1959 and, ideally, in a non-distant future by extrapolating the Cuban-USSR experience from 1970 to 1990. More recent Cuban and US input-output tables are available to initiate the impact studies.

Consequently, this section reflects the possible application to the Cuban-US situation of the conclusions of a first attempt to combine an empirical socio-economic input-output analysis with a historical approach to determine the reciprocal impacts of the Cuban economy and the USSR economy. Static input-output models of the Cuban and USSR economies were combined with dialectical interpretations of their socio-economic relationship, from 1970 to 1990 (Pellet, 1986). A multiplier approach was used to measure the role of different 
sectors in each economy. In addition, the direct, indirect and induced effects per unit of currency of final demand were considered.

The results of these computations reflected that the total cost to the USSR of supporting the Cuban economy was much larger than the available data would suggest. In other words, the total requirements of resources in terms of output, income and employment were larger than the direct costs involved. The use of input-output models allows measuring the indirect impacts that normally are omitted in other approaches that underestimate real costs because they only consider the direct impacts. However, the USSR saved resources by exporting capital-intensive products and by importing labor-intensive goods. This complementarity evidenced the applicability of the law of comparative advantage, that is, the overall efficiency in the area of international trade increases when each country allocates its resources in those sectors in which each one is more efficient or less inefficient. This situation also validated the Heckscher-Ohlin-Stolper-Samuelson theorem, which states that each country tends to export goods and services that use intensively its more abundant resources (Pellet, 1986 and 1978).

Before 1959, the existence of US subsidies (due to the most favorable nation policy) for sugar imports from Cuba made sugar production a more profitable activity in comparison with many other exportable goods, i.e. in 1920, 3.75 cents per pound, which was higher than the average price between 1885 and 1914. These subsidies affected many investment decisions in the sense of favoring the concentration and expansion of economic activity in the sugar sector (Pellet, 1976). Similar impacts could be related to subsidies for imported oil and cereals or exports of minerals and fruits. Although from a purely economic point of view, these subsidies constituted a very unorthodox inducer of the law of comparative advantage, at same time, perpetuated an unhealthy socio-economic dependence of Cuba in the production of sugar (Pellet, 1976).

In a post-revolutionary future, by using the Soviet 1970-1990 era input-output experience, Cuba could reverse the structural transformation of its centrally-planned economy into a market-oriented one, allocating its resources to purchase capital-intensive products, like airplanes, automobiles, trucks, heavy machinery and electronics from countries like the United States or Europe and sell labor-intensive products, and at the same time continue with the effective diversification process that was interrupted when the Cuban economy was forced, for political reasons, to be transformed from a market-oriented into a centrally-planned economy (Pellet, 2007).

\section{Trade Flow between Cuba and the United States before 1959}

Trade flow between the U.S.A. and Cuba could be explained in terms of the Adam Smith's theory of absolute advantage, David Ricardo's theory of comparative advantage and the Heckscher-Ohlin-Stolper-Samuelson's theorem, assuming a market-oriented socio-economic context as was before the 1959. During the 1959-1965 period, Cuban economy experienced a forced transformation into a centrally planned model, creating a dislocation of the price mechanism due to the fact that prices in centrally-planned economies were determined through extensive negotiation, and not by the interactions of supply and demand. These prices were generally based on the average price over a time span in an effort to minimize inflationary and speculative impacts.

One of the most important methodological problems encountered in analyzing Cuban trade data is that the information on pricing is sometimes non-existent due to a different philosophical approach to the nature of costs, prices, value and money in market-oriented versus Marxist-Leninist type of centrally-planned economies (Pellet, 2014). Consequently, this data had to be determined by computing the average value of exports / imports for specific products, using the cumulative value of the products in addition to the number of units exchanged for that value. This method lend itself to distortions as changes in total value can be derived from many factors other to pure price. For example, a change in the export/import unit value would be affected by a change in product quality or composition or discounts, without identification of the factor responsible for such change. For example, the current Cuban monetary system uses significant subsidies to state enterprises, and has implemented a dual-currency system, with the $(C U P)$ peso used internally by the population, and the CUC (Cuban Unit of Currency) approximately equivalent to the US dollar, that is, between 24 to 25 times the real buying power of the CUC peso, imposed in all forms of international transactions, including tourism.

Cuba used to export coffee, fruits, nickel, tobacco, vegetables with a positive balance of trade to the United States before 1959; nowadays the Island has to import more than 50\% of its energy and $75 \%$ of the nation's food. Of course, cyberspace technology will have a positive impact on both exports and imports of each 
country in the years to come due to the relevance of instant and asynchronous communication (Moen, Madsen \& Aspelund, 2008).

The United States has an absolute advantage in exporting agricultural products, processed foods, and services, such as financial, professional, business, or technical services and has an absolute advantage in producing aircraft, which it can export to Cuba. On the other hand, the United States does not have an abundance of cheap labor to produce plastics, toys, and textiles. Cuba has absolute and comparative advantage in producing certain products because of their knowledge, geography, and cheaper labor, such as nickel, fruits, sugar, coffee, tobacco, rum, and eco-tourism related activities, which could eventually be exported to the United States. If each country trades with the other based on their comparative advantage, then both American and Cuban consumers would benefit. International trade between the United States and Cuba would also provide opportunities for further enhancing diplomatic relations, which is supported by most individuals who are ethnically linked to Cuba (Grenier and Gladwin, 2018, p. 14). As presented in Figure 4, about 63\% of the respondents said yes to better diplomatic relations between Cuba and the United States.
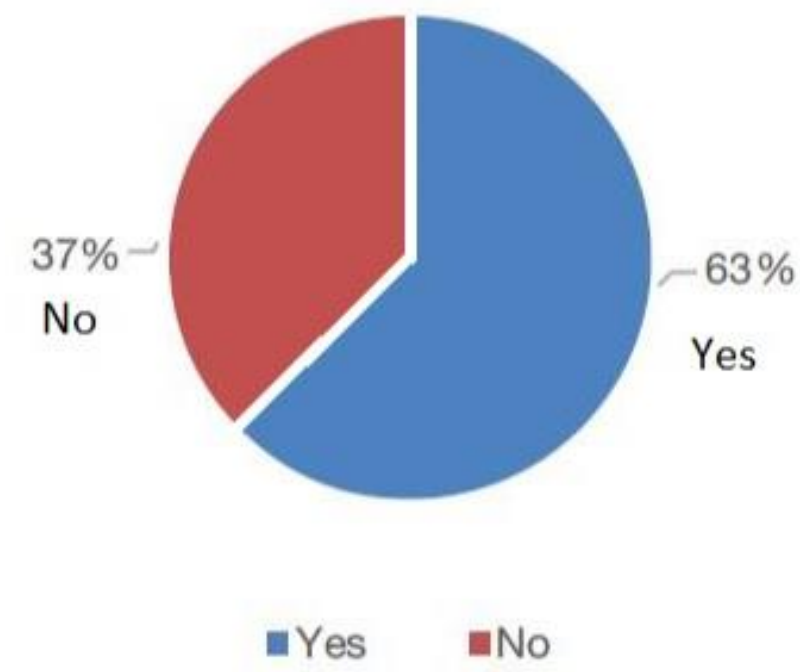

Figure 4. Cuban-Americans Support Diplomatic Relations

Source: Grenier and Gladwin, 2018, p. 14 (Link: https://sipa.fiu.edu/academics/research/2018-fiu-cubapoll.pdf).

\section{Conclusions}

Cuba is a Caribbean country in transition. Today, it is still under the control of a waning totalitarian government and faced with global pressure to modernize; however, there is potential for change that suggests more opportunities for international trade with American businesses. Before major economic change can take place, considerable cultural change is needed. A shift away from the collectivism of Marxist-Leninist Stalinist socialism towards a more moderate acceptance of personal freedom will allow for the return of private ownership of means of production and the freedom to pursue one's self-interest through various forms of business and international trade (Pellet, 1976, 1986 and 2007). A freer, less controlled Cuba can more efficiently interact with the world markets and take part in the benefits of globalization.

There will be a political conflict involving the expansion of businesses into Cuba because it is the country's political system that control and regulates business. That conflict will be conducted through legal restrictions on ownership or trade on the part of the Cuban government and pressure towards private ownership and free trade on the part of the United States government.

Capitalist economies are not perfect nor are they entirely efficient but they are superior to command economies in technological efficiency and in the opportunity to provide a better lifestyle for a greater portion of the country's citizens. For this reason, a transition to a free enterprise economy should be incentivized in Cuba subtly through external foreign investment and influence. Once the country as a whole is prepared to transition, preferably non-violently, there are strategies to be implemented to best position a company within the new market. 
International free and fair trade allows a country's national economy to flourish. Nations that trade with one another benefit in many ways, especially by advancing their economies, improving the lifestyles and quality of life for their citizens with better wages, offering consumers more product choices, and making the country more competitive. Theories of absolute advantage, comparative advantage, and exports explain the trade flows between nations. Free and fair trade agreements provide excellent opportunities for countries to prosper as they specialize in what they can produce and trade more efficiently or less efficiently with others. Public sector officials and policy-makers can implement appropriate policies that affect a country's competitiveness in international trade, either holding it back or rendering it a competitive international leader. Policy makers, entrepreneurs, and managers must be aware of all of these aspects of international trade in order to take full advantage of all that the global economy has to offer.

Governments and policy makers should play a proactive role in promoting national competitive advantage in industries where they have plenty of resources. Countries that participate in international trade will eventually realize an economic gain. There has to be parameters in place to encourage fair practices. Governments can help protect jobs and manage risks to their national security. As such, we believe that both the American and Cuban citizens can benefit from free and fair international trade between the United States and Cuba as each nation brings specific advantages that are unique to each cultures. As such, current Cuban and American leaders should do everything they can to make international trade an effective and continuous process among these two neighboring countries.

Finally, utopic ideologies should not prevail over economic pragmatism, and human life, liberty and the pursuit of happiness must be prioritized, paraphrasing the U.S. Declaration of Independence, with the following principles in mind: 1) The primacy of spiritual values; 2) Respect for human life and dignity, in particular, and of all forms of life, in general; 3) The integral development of all members of the human family; 4) The search for truth and justice among all women and men; 5) Faith in education as a means of improving both societies and humanity; 6) A mission of service to the people, in general, and to the most vulnerable members of society, in particular; and 7) A pledge to the ideal of representative democracy and the protection of minorities.

In accordance with these principles, global economies should be oriented in order to contribute to the development of an intellectual, ethical and moral international trade environment in which the arts and sciences may be cultivated. Economics must serve humankind and not vice versa.

\section{References}

1. Amadeo, K. (n.d.). 7 Pros and 7 Cons of Trade Agreements. The Balance. Retrieved from https://www.thebalance.com/free-trade-agreement-pros-and-cons-3305845.

2. Agarwal, Prateek. (December 20, 2017). Absolute Advantage. Intelligent Economist. Retrieved from: https://www.intelligenteconomist.com/absolute-advantage/.

3. Al Jazeera and news agencies. (2016, 12 13). Cuba signs deal with Google for faster internet access. Retrieved from Al Jazeera: http://www.aljazeera.com/news/2016/12/cuba-signs-deal-google-fasterinternet-access-161213060258481.html.

4. Baden, Ben. (March 15, 2013). What America Exports to China. China Business Review. Retrieved from: https://www.chinabusinessreview.com/what-america-exports-to-china/.

5. Berger, B. H. (2018). Advancing the ASEAN Economic Community: The role of China and Japan in supporting ASEAN's regional integration. In China and Japan in the Global Economy (pp. 120-144). Routledge.

6. Gilpin, R. (2018). The challenge of global capitalism: The world economy in the 21st century. Princeton University Press.

7. Burnett, V. (2015, 04 17). Barriers remain for American business in Cuba: Removal from terror list goes only so far in easing business ties with island. International New York Times [Paris], p. 14.

8. Cavico, F. J. and Mujtaba, B. G. (2016). Developing a Legal, Ethical, and Socially Responsible Mindset for Sustainable Leadership. ILEAD Academy: Florida.

9. East and Southeast Asia (November 4, 2011). Retrieved April 15, 2017 from website: Central Intelligence Agency. The World Factbook: https://www.cia.gov/library/publications/the-worldfactbook/geos/hk.html. 
SocioEconomic Challenges, Volume 3, Issue 1, 2019

ISSN (print) - 2520-6621, ISSN (online) - 2520-6214

10. Grenier, G. J. and Gladwin, H. (2018). 2018 FIU CubaPoll: How Cuban Americans in Mimai View U.S. Policies Toward Cuba. Link: https://sipa.fiu.edu/academics/research/2018-fiu-cuba-poll.pdf; https://sipa.fiu.edu.

11. Flores, V. (2016). Cuba: The Last One to the Global Economic Table. Law and Business Review of the Americas, 4, 59-67.

12. Foreign Trade (2008). Country Commerce. Hong Kong, 83-90. Retrieved on April 15, 2017 from: http://web.ebscohost.com.resources.njstate-

lib.org/ehost/pdfviewer/pdfviewer?vid=5\&hid=111\&sid=7608bc34-fde8-47e2-ac13adf14ccaa8d6\%40sessionmgr114.

13. Frank, M., \& Rathbone, J. P. (2018, May 8). Cuba in drive to attract foreign investment. Retrieved from: https://www.ft.com/content/9ef0f118-4fcd-11e8-a7a9-37318e776bab.

14. Hall, Robert, and Charles Jones (1999). Why Do Some Countries Produce So Much More Output Per Worker Than Others? Quarterly Journal of Economics, 114, 83-116.

15. Hill, C. W. (2011). International business: Competing in the global marketplace. New York: McGrawHill.

16. Hill, C. W. and Hult, G. T. (2017). International business: Competing in the global marketplace. New York: McGraw-Hill Education.

17. Kapcia, A. (2012). The Cuban Revolution in the 21st Century. Capital \& Class, 8, 187-189.

18. Luthans, F. \& Doh, J. (2018). International Management: Culture, Strategy, and Behavior (10 ${ }^{\text {th }}$ Ed.). McGraw-Hill: New York.

19. Marsh, S. (2018, July 17). Communist-run Cuba starts rolling out internet on mobile phones. Retrieved from: https://www.reuters.com/article/us-cuba-internet/communist-run-cuba-starts-rolling-out-interneton-mobile-phones-idUSKBN1K62U7.

20. Kenton, W. (March 28, 2018). Mercantilism. Retrieved from Investopedia Website: https://www.investopedia.com $/$ terms $/ \mathrm{m} /$ mercantilism.asp.

21. Mercantilism (2018). Retrieved from Business Dictionary. Website: http://www.businessdictionary.com/definition/mercantilism.html.

22. Moen, Ø., Madsen, T. K. \& Aspelund, A. (2008). The importance of the internet in international businessto-business markets. International Marketing Review, 25(5), 487-503. DOI: $10.1108 / 02651330810904053$.

23. Mujtaba, B. G. (2015). Globalization and International Business Trends. YouTube link: https://www.youtube.com/watch?v=vDn4lGRb_js.

24. Mujtaba, B. G. (2014). Managerial Skills and Practices for Global Leadership. ILEAD Academy: Davie, Florida.

25. Pellet, Pedro F. (1986). Socio-Economic Models and the Impacts of a Small Socialist Economy on an Industrialized Society: The Cases of Cuba and the USSR in Historical Perspective. Ph.D. Dissertation in Socio-Economic Development, University of Miami.

26. Pellet, Pedro F. (2007). Políticas y Estrategias para la Reindustrialización de Cuba en el Período PostRevolucionario. Monografía Publicada con el Profesor Mario E. Delgado en el libro titulado El Futuro de la Economía Cubana: Ensayos e Investigaciones, que Recoge los Diferentes Trabajos de la Séptima Conferencia Anual del Colegio de Economistas Cubanos. Universidad de Miami, Instituto de Estudios Cubanos y Cubanoamericanos. Coral Gables, Florida. Editora Corripio, C. por A., Santo Domingo, República Dominicana, Febrero, 2007. ISBN 978-1-4243-3350-9.

27. Pellet, Pedro F. (2014). Cuba's Development Index (HDI). Refereed Paper with Professor Emeritus, Irma Tirado de Alonso, Ph.D., Florida International University, Professor Antonio A. Fernández, M.D., Barry University and Professor María I. Méndez, M.B.A., Miami-Dade College. Presented at the International Academy of Business and Public Administration Disciplines. Madrid, Spain, July $24^{\text {th }}, 2014$.

28. Perez M. (n.d.). In Cuba, self-made mechanics keep the country's classic cars on the road, and help the economy. Retrieved from: http://www.mcgrawcenter.org/stories/in-cuba-self-made-mechanics-keep-thecountrys-classic-cars-on-the-road-and-help-the-economy/.

29. Piccone T. \& Trinkunas H. (2016, July 28). The Cuba-Venezuela Alliance: The Beginning of the End? Retrieved from: https://www.brookings.edu/research/the-cuba-venezuela-alliance-the-beginning-of-theend/.

30. Porter, M. E. ( March-April 1990). The Competitive Advantage of Nations. Harvard Business Review 68,(2): 73-93. 
31. Rapoza, Kenneth. (September 20, 2011). The Things China Can Buy From US. Forbes. Retrieved from: https://www.forbes.com/sites/kenrapoza/2011/09/20/the-things-china-buys-from-the-us/\#55f1f7905f70.

32. Reid, R.L. (2008). Report Warns U.S. Economy Depends on Transportation Infrastructure and Land Use Planning. Civil Engineering (08857024), 78(8), 28-30. Retrieved on April 15, 2017 from: http://web.ebscohost.com.resources.njstatelib.org/ehost/pdfviewer/pdfviewer?vid=18\&hid=112\&sid=9ae9519a1d4d-444d-b31c-3d6b8bf12076\%40sessionmgr110.

33. Sanyal, R. (2006). International Management: A Strategic Perspective. Boston, MA: Pearson Custom Publishing.

34. Seyoum, Belay (2014). Export-Import Theory, Practices, and Procedures ( $3^{\text {rd }}$ edition). Routledge: New York. PDF link: http://rafael.glendale.edu/poorna/ib/seyoum\%20book.pdf.

35. Sweig, J. E., \& Bustamante, M. J. (2013). Cuba After Communism: The Economic Reforms That Are Transforming the Island. Foreign Affairs 92.4, 101-114.

36. Symmes, P. (2015, 04 01). The Cuban Money Crisis. Retrieved from Bloomberg: http://www.bloomberg.com/news/features/2015-04-01/cuba-s-new-money.

37. Truman, T. (November 1, 2011). Hong Kong Trade Agency Recognized for Support of U.S. Exports. Tradeology. The Official Blog of the ITA. Retrieved on April 15, 2017 from: http://blog.trade.gov/2011/11/01/hong-kong-trade-agency-recognized-for-support-of-u-s-exports/.

38. U.S-Cuba Trade and Economic Council, Inc. (2014). Retrieved from: https://static1.squarespace.com/static/563a4585e4b00d0211e8dd7e/t/5ab909430e2e72df80df7d92/1522 075971963/USCompaniesAndCuba.pdf.

39. US State Department. (2016). A Guide to the United States' History of Recognition, Diplomatic, and Consular Relations, by Country, since 1776: Cuba. Retrieved from US Department of State: Office of the Historian: https://history.state.gov/countries/cuba.

40. Zillio, G. (September 20, 2016). Trade Dynamics and China, Part 3: How Do the United States and China Compare? Retrieved from https://www.frbatlanta.org/economy-matters/2016/09/20/trade-dynamics-andchina-part-three.

41. What are the U.S. and China's Current Comparative Advantages? (2010). Future of U.S. China Trade.com. Retrieved from: http://www.futureofuschinatrade.com/article/us-and-china-current-comparative-advantages.

42. Whitefield, M. (2016, July 12). Study: Cubans don't make much, but it's more than state salaries indicate Retrieved from: https://www.miamiherald.com/news/nationworld/world/americas/cuba/article89133407.html.

43. Wolfe, L. R. (2016, May 2). American Business in Cuba. Retrieved from: http://www.havanaproject.com/2011/08/american-business-in-cuba-1898-1959-a-brief-overview/. 